\title{
Entrepreneurship for Empowerment Persons With Disabilities In Yogyakarta Province
}

\author{
Arni Surwanti \\ Master Management Departement \\ Universitas Muhammadiyah Yogyakarta \\ Yogyakarta, Indonesia \\ arni.umy@gmail.com
}

\author{
Lela Hindasah \\ Department of Management \\ Universitas Muhammadiyah Yogyakarta \\ Yogyakarta, Indonesia \\ lel_umy@yahoo.com
}

\begin{abstract}
The Local Regulation of Protection and Fulfillment of the Rights of Persons with Disabilities in Yogyakarta Province mandates that every person with disabilities has the same rights and opportunities to get a job. The government has obligation to facilitate persons with disabilities to get a job. The local governments in provincial and regency levels need to expand economic empowerment for Persons with Disabilities through entrepreneurship. This study provided an overview of the business sectors carried out by persons with disabilities, the key success, obstacles and challenges of persons with disabilities in running their own business. This research can be used to give recomendation to the government.
\end{abstract}

Keywords-Entrepreneurship, Persons with Disabilities

\section{INTRODUCTION}

\section{A. Demography and Policy}

Yogyakarta Province has 5 regencies/cities: Bantul, Sleman, Gunung Kidul, Kulon Progo and Yogyakarta City. Based on a population census in 2011, the population of Yogyakarta Province were 3,513,071 persons. Based on the World Report on Disability in 2011, the number of persons with disabilities was $15 \%$ of the total population. Persons with Disabilities (PwDs) in Yogyakarta Province based on a population census and World Report on Disability in 2011 are as shown in the following table:

Table 1. Population of Persons with Disabilities in Yogyakarta Province

\begin{tabular}{ccc}
\hline Regencies & $\begin{array}{c}\text { Population of Persons with } \\
\text { Disabilities }\end{array}$ & $\begin{array}{c}\text { Total } \\
\text { Population }\end{array}$ \\
\hline Bantul & 138,189 & 921,263 \\
Gunung & 101,307 & 675,382 \\
Kidul & 150,870 & $1,005,797$ \\
Sleman & 70,573 & 470,486 \\
Kulon Progo & 66,021 & 440,143 \\
Yogyakarta & 526,961 & $3,513,071$ \\
\hline Total & &
\end{tabular}

The data collection for the number of persons with disabilities until now still faces problems that need solution in the future because there is no clear definition of PwDs [1], so it is not surprising that the number of persons with disabilities recorded in villages sub districs is only a few. At present, persons with disabilities still face issues related to their welfare. The characteristics of persons with disabilities in Yogyakarta Province are: Almost $89 \%$ live in rural areas; coming from a family whose social, economic and health status is low; gnerally having a low level of education and skills; having a relatively low productivity as human resources because there is no opportunity to get vocational training; still facing psychological problems such as feeling ashamed, not confident, or fear when leaving the house. There are still social and cultural barriers; there is discrimination from family and environment as well as physical barriers, i.e. unavailability of accessible public facilities; difficulty in accessing capital; incapability to sell their products.

Efforts to empower persons with disabilities have been implemented by the government. This can be seen on the issuance of various laws and regulations on Persons with Disabilities since 1997, even this law still based on charity approach [2] This law should be more comprehensive and can serve as a basis for the implementation of Government Policy of Social Welfare for Persons with Disabilities. In addition, tjere isLaw No. 6 of 1974 on the Principles of Social Welfare [3], which has been used as the basis for the application of Government Programs in Social Welfare of Persons with Disabilities. Besides, the government of the Republic of Indonesia has adopted the results of local and international conventions.

In Asia and Pacific region to end the Decade of Persons with Disabilities, 1993 2002, UN-ESCAP held a High-Level Intergovernmental Meeting on October 25-28, 2003, in Otsu City, Shiga, Japan. The ESCAP resolution was entitled "Promoting an inclusive, barrier-free and rights-based society for persons with disabilities in the Asian and Pacific region in the twenty-first century", as outlined in the Biwako Millennium Framework for Action (BMFA). In BMFA the theme was "Inclusive Society", "Barrier-Free Society" and "Rights-Based Society", by establishing 7 action plans [4], 
which were then adopted into National Action Plan (RAN) Indonesia 2004-2013 [5]. They are Empowerment of nongovernmental organizations with Disabilities, family associations and parents with disabilities; Empowering women with disabilities; Early detection, early intervention and education; Training and work placement including selfemployed; Access to build environment and public transportation; Access to information and communications including information technology, communications, and tools. Poverty alleviation lets businesses develop social safeguard / survival programs; International Relations.

The High-level Intergovernmental Meeting on the Final Review of the Implementation of the Asian and Pacific Decade of Disabled Persons, 2003-2012, was organized by ESCAP and hosted by the Government of the Republic of Korea and launched the new Decade. The Governments at the High-level Intergovernmental Meeting adopted the Ministerial Declaration on the Asian and Pacific Decade of Persons with Disabilities, 2013-2022, and the Incheon Strategy to "Make the Right Real" for Persons with Disabilities in Asia and the Pacific. The Incheon Strategy provides the Asian and Pacific region, and the world, with the first set of regionally agreed disability-inclusive development goals. The Incheon Strategy builds on the Convention on the Rights of Persons with Disabilities and the Biwako Millennium Framework for Action and Biwako Plus Five towards an Inclusive, Barrier-free and Rights-based Society for Persons with Disabilities in Asia and the Pacific [6].

In 2012, the Asia-Pacific Development Center on Disability also socialized the prospect of "Disability-Inclusive Business" as a business strategy concept by including the issue that persons with disabilities are customers, employment, employers and employers, a potential prospect to be implemented in Asia Pacific. This concept superseded the conventional concept of CSR/Corporate Social Responsibility using a charity-based approach, where persons with disabilities were treated only as beneficiaries.

In 2011 it was a major milestone that provided an important step for persons with disabilities in Indonesia after three years, since March 30, 2007 Indonesia signed the Convention on the Rights of Persons with Disabilities (CRPD), finally on October $18^{\text {th }}, 2011$ Indonesia ratified the CRPD, and as of November 10, 2011, the Law on the Ratification of the Convention on the Rights of Persons with Disabilities/UN-CRPD [7]. In May 2016, another law was issued, i.e. Law No. 8 on the rights-based disabled, replacing Law No. 4 of 1997 which was charity-based approach. The Convention on the Rights of Persons with Disabilities (UNCRPD) in Yogyakarta Province also resulted in Local Regulation No. 4 of 2012 on Protection and Fulfillment of the Rights of Persons with Disabilities [8]. This regulation provides an important meaning in order to ensure the realization of the rights of PwDs in Yogyakarta Province. Despite the existence of legislation at the international, national and local levels, until now, the implementation of local regulation has not given any significat impact.

Characteristics of PwDs are only well understood by the Social Affairs Department in local government, but other departments in local governments still do not understand who persons with disabilities are. Similar situation also occurs among the government officials at village and subdistrict levels. Their understanding of persons with disabilities is those who can only lie down. Thus it is not surprising that the number of persons with disabilities recorded at the village and sub district levels is only a few. The implementation of the new Population Census conducted in Indonesia was unable to correct the recordregarding the number of persons with disabilities in Indonesia. This is reflected in the data collection instrument which does not clearly represent the existence of persons with disabilities. The government in Yogyakarta Special Region also shows no effort to alter the paradigm in dealing with PwDs, such as handling of PwDs using charitybased approach and focus on PwDs in an institution. This problem is exacerbated by limited government budget. In addition, the government's commitment to providing social assistance and empowerment for PwDs is not accompanied by good implementation and supervision processes, so that there are many deviations in the field.

In terms of employment, LocalLocal Regulation No 4 of 2012 on the Protection and Fulfillment of the Rights of Persons with Disabilities mandates that all persons with disabilities have equal rights and opportunities to find employment. The government is obliged to provide facilitation for persons with disabilities to get a job. Local Governments and Regency/Municipal Governments should also extend employment opportunities for persons with disabilities in sustainable self-employment, thereby employment opportunities for persons with disabilities can be made through intrapreneurs where persons with disabilities can bec

ome workers or entrepreneurship where persons with those with disabilities can establish independent businesses. This study provided an overview of the sectors of independent businesses that could be undertaken by PwDs, the keys to success and the challenges that PwDs might deal with when running their own businesses, and to what extent is the role of local governments in supporting PwDs business after 4 years of the issuance of Local Regulation No 42012 on the Protection and Fulfillment of the Rights of Persons with Disabilities.

\section{B. Persons with Disabilities}

Referring to Local Regulation No 4 of 2016, Persons with Disabilities are any person who experiences disturbance, disorder, damage, and/or loss of physical, mental, intellectual or sensory organ function for a certain period or permanent and faces physical and social environmental barriers [9]. The types of disability may include: visual impairment that can 
occur due to various causes, such as accidents, illness and other causes; hearing disorders that is partial or total inability to hear sound on one or both ears; speech disorders that is a person's difficulty to speak due to, among other things, interference with the throat organs, vocal cords, lungs, mouth, tongue, and consequences of hearing loss; motor disturbance and mobility that is disability that affects a person's ability to control muscle movement that sometimes limits mobility; cerebral palsy that is a disorder or abnormality that occurs in a period of time in the development of children, related to motor cells in the central nervous system, chronic and not progressive due to abnormalities in the incomplete growth of brain tissue;attention and hyperactivity disorder that is a child who always moves, taps a finger, wags his legs, pushes another child's body for no apparent reason, speaks endlessly, hyperactive; autism that is a condition of a person from birth or during infancy, which makes him unable to form a normal social or communication; epilepsy that is a chronic disease that causes sudden seizure unreasonably; tourette's syndrome that is a neurological disorder that appears in childhood characterized by repetitive motor movements and sounds; social, emotional, and behavioral disorders that are individuals who have deviant and abnormal behavior, have no attitude, violate rules and social norms; mental retardation that is a condition before the age of 18 years characterized by a low intelligence (usually the IQ score is below 70) and difficult to adapt to everyday life.

Although the characteristics of persons with disabilities in Yogyakarta Province are generally still apprenticeship but they have considerable potential to develop. Employment and self-employment (running their own business) opportunities will come if they are given the support and opportunities to develop themselves, improving the welfare of persons with disabilities.

\section{Role of Government in Employment for Persons with Disabilities}

All Persons with Disabilities have equal rights and opportunities to find job and / ordecent work. Some of the activities regulated in Local Regulation No 4 of 2012 article 17-29 on the Rights to Employment especially in facilitating the expansion of employment opportunities through selfemployment are as follows:

Job training. Every Disabled Employee has the right and opportunity to receive job training to improve his/hercompetence in accordance with individual conditions and needs. Job training is conducted in stages, i.e. basic until advanced level. Job training can be organized by Local Government; Regency / Municipal Government; Organization of social rehabilitation; Community institutions; and Companies that employ Persons with Disabilities.

Training Certificate. The provider of job training is required to provide a training certificate for participants with
Disabilities as proof of completion. The completion certificate contains a level of competency possessed by persons with disabilities.

Self Employment. Local Government and Regency/Municipal Government shall extend employment opportunities for Persons with Disabilities in the form of productive and sustainable self-employment. Persons with disabilities need to be facilitated to run their own business in many kinds of business sectors.

Self-employment guidance for Persons with disabilities. Governmental organization in provincial and regency levels have duties and functions in providing selfemployment guidance in terms of running business by Persons with Disabilities. The guidance can cover how to increase product quality, how to sell product, how to finance their business etc.

Cooperation and partnerships with business actors. Local Governments and Regency/Municipal Governments shall encourage and facilitate efforts to strengthen and develop economic enterprises of PwDs through cooperation and partnerships with business actors. The partnership can be in the forms of giving sub contract, providing raw material or encouraging the improvement product quality of PwDs.

Allocating a part of production or distribution process of their business. Local Government and Regency / Municipal Government shall encourage and facilitate business actors to allocate a part of the production or distribution process of their business to Persons with Disabilities.

Access to Capital from Financial Institution. Local Governments have obligation to facilitate Persons with Disabilities to obtain equal rights and opportunities in obtaining capital from financial institution for business development. Banking and non-bank financial institutions owned by LocalLocal Government and/or Regency / Municipal Government and private sector are obliged to provide capital access to PwDs in accordance with the applicable regulations.

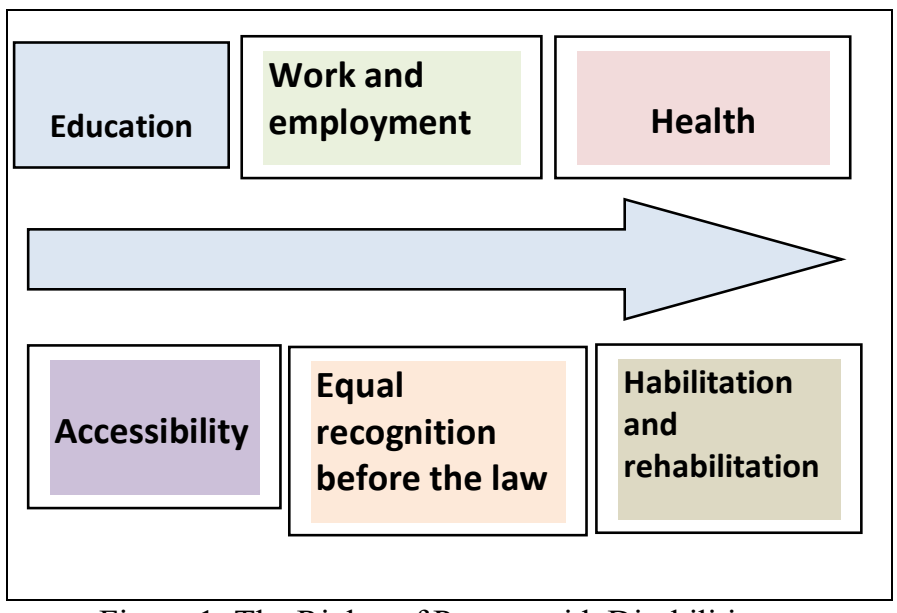

Figure 1: The Rights of Person with Disabilities 
Employment right is one of the rights that must be fulfilled by the government. There are many other rights that become the responsibility of the government to protect and fulfill. The rights of persons with disabilities that should be considered because they affect the welfare of persons with disabilities, are described in the fishbone diagram as shown on Figure 1.

\section{Entrepreneurship}

The word entrepreneur has been known since the 17th century. The word entrepreneur has meaning of bravery and effort. Thus, entrepreneurship means a person who is perseverant or determined in an effort [10]. The Great Dictionary of Indonesian Language defines entrepreneur as being smart or talented to recognize new products, determining a new way of production, arranging operations for the procurement of new products, marketing it and managing its operations. According to [11], entrepreneur is a person who has the energy, the desire to get involved in innovative adventures, the willingness to accept personal responsibility for the realization of an event in the way they choose, and the desire for a very high precision.

According to [12], entrepreneur is someone who creates a new business by taking risks and uncertainties in order to achieve profit and growth by identifying opportunities and combining the resources needed to establish them. Based on the opinions of experts described above, there is a common trait that is always present in an entrepreneur, namely the ability to change something for the better or create something really new, known as creative and innovative. Entrepreneurship is spirit that can also have two meanings as a mental attitude and entrepreneurial spirit that can be applied in all places and areas of work, and also means a field of work itself. Mental attitude and entrepreneurial spirit are an absolute prerequisite for someone who wants a more qualified life.

According to [13], an entrepreneur should have the following criteria such as having commitment, having mind and heart that focus on the development of the business he is doing, having consistency, believing in the importance of process because nothing is instantaneous, having high productivity, utilizing time productively means forcing to recognize all the talents that exist in life, taking actions efficiently and effectively, both of these measures will be very helpful in planning the activities that will be carried out, having other criteria: having a leadership spirit [14] and willing to take risks [15], having initiatives [16]. According to Mulyadi [17], entrepreneuship means hard workers who dare to take responsibility and innovative.

The objectives of this research were to identify the independent business sectors undertaken by PwDs in Yogyakarta Province; to analyze the key success factors as well as the obstacles and challenges faced by persons with disabilities in running business; to identify the roles of local government in supporting self-employment conducted by persons with disabilities in Yogyakarta Province after the issuance of Local Regulation No. 4 of 2012.

\section{METHODS}

\section{A. Object of Research and Sampling Technique}

In order to answer the research problem regarding the analysis of entrepreneurship of PwDs, this research examined PwDs who had their own business. The research objects were micro, small and medium enterprises run by persons with disabilities in Yogyakarta Special Region covering 5 regencies/cities i.e. Sleman, Gunungkidul, Kulon Progo, Bantul and Yogyakarta City.

Other institutions involved in the implementation of economic empowerment of PwDs program are the provincial government of Yogyakarta and regency governments as the stakeholders. The sample of this research was selected by purposive sampling method, that is sampling using special consideration. The considerations used were: research of independent entrepreneur program actors who were incorporated into organizations of persons with disabilities at the provincial and/or regency levels, and research on persons with disabilities as beneficiaries was done on those who once received governmental program services in self-employment.

\section{B. Research Data and Data Collection Techniques}

This was a descriptive research, using primary data which were directly collected from the research objects. The data used were primary data and secondary data. The primary data were used to explore information about selfemployment sectors undertaken by persons with disabilities in Yogyakarta Province, as well as to explore information about the key success factors and challenges faced by self-employed persons with disabilities in Yogyakarta Province. The secondary data were used to explore information about the roles of local government in supporting self-employment by persons with disabilities in Yogyakarta Province after the realization of Local Regulation No. 4 of 2012. The primary data were obtained from the respondents, i.e. their answers to some semi-closed questions using different research settings. The settings used were surveys using mail surveys, direct interviews through Focus Group Discussion, and dissemination.

\section{Analysis used}

This research was a qualitative research by using descriptive explorative approach in analyzing the existing problems. Descriptive explorative approach was used because of the nature of this research which aimed to reveal any phenomenon related to the problem in order to develop the expected design so that the results to be achieved. This study also focused on the key success factors and challenges faced by self-employed persons with disabilities. The approach used was an integrated approach, i.e. researching from persons with disabilities as beneficiaries of self-employment program and local government as stakeholders. 


\section{Research Design}

One Year Research: Evaluation and Exploration. The objectives to be achieved during the study period were to identify the independent business sectors undertaken by persons with disabilities in the Province of Yogyakarta Special Region, analyze the key success factors as well as the obstacles and challenges faced by self-employed entrepreneurs/persons with disabilities in the Provinceof Yogyakarta Special Region, and identify the roles of local government in supporting self-employment undertaken by persons with disabilities in the Province of Yogyakarta Special Region after the issuance of LocalLocal Regulation No 4 of 2012.

\section{RESULTS AND DISCUSSION}

\section{A. Identification of self-employment sectors undertaken by} persons with disabilities in Province of Yogyakarta Special Region

One of the efforts to provide employment opportunities for persons with disabilities is to conduct self-employment. Self-employment that is run by persons wth disabilities can be included in the group of Micro, Small and Medium Enterprises (MSMEs). The classification of economic activities referred to the concept of ISIC (International Standard Classification of All Economic Activities) which was revised in 1968. Based on the grouping, the business of PwDs is mostly in the group of Agriculture, Livestock, Forestry and Fisheries; Processing Industry; Trade, Hotel and Restaurant; Transport and Communications; Services [13]. The description of the business done by persons with disabilities is as follows:

1) Processing industry. Food processing industries are what persons with disabilities most often undertake, for examples making snacks such as various chips by using various raw materials like wheat flour, mocaf flour etc,

2) Agriculture, Animal Husbandry, Fisheries. Several persons with disabilities also work in Agriculture, Animal Husbandry, Fisheries. Some of them are able to grow rice, cassava, peanut. Poultry, including duck farming and fish farming are also an option for the entrepreneurship run by persons with disabilities. Fish farming is usually in the form of freshwater fish farming such as catfish, either in the form of breeding or farming

3) Trade, restaurant. Persons with disabilities are more frequently found to work in the general trading sector. The type of trading business that many persons with disability do is groceries trade. Micro sized restaurant business is more often called as food stall, more especially a popular food stall in Yogyakarta named angkringan. The food they sell includes rice, fried chicken, satay and others. Meanwhile, the beverages varysuch as tea, orange juice, coffee, ginger tea and milk. All are offerred at very affordable prices.

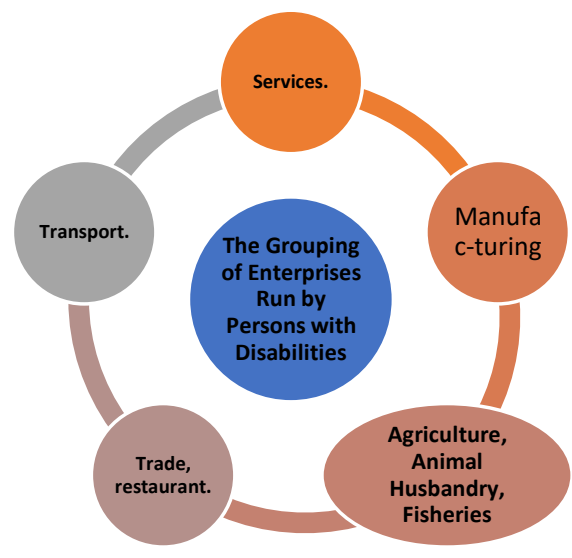

Figure 2. Grouping of Enterprises Run by Persons with Disabilities

4) Transport. A number of persons with disabilities in Yogyakarta joined a motorcycle taxi business using modified vehicles. Two-wheel motorcycle is modified by adding a sidecar to be able to carry passengers with a wheelchair. This modified motorcycle taxi is needed by persons with disability because it is a cheap mode of transportation that public transporttaion does not offer. Motorcycle taxi business is managed by persons with disabilities and the drivers are also PwDs.

5) Services. Service businesses that persons with disabilities often undertake are massage and sewing services. Massage services are usually done by blind persons. They usually rent a house and start a massage business, where customers can come to this place, or if they want to get the massage service at their home, they could call them to come. Similarly, sewing service is also a type of business that is often offered to persons with non-blind disabilities. Beauty salon service business is also a business option run by persons with disabilities, be it hair salon, makeup services, bridal makeup.

Analysis of key success factors as well as obstacles and challenges faced by self-employed entrepreneurs' persons with disabilities in the Province of Yogyakarta Special Region.

\section{B. General Obstacles and Challenges in Micro Enterprises}

The Indonesian Banking Development Institute divides companies in Indonesia by business sizes into 4 (four) business groups: micro, small, medium and large enterprises [18]. The grouping of business is based on asset size and turnover. The division of companies based on their asset sizes and turnovers can be seen in Table 2. Based on the sizes of the company, the average business run by persons with disabilities is still in the micro business category because the sales turnover is still IDR 300,000,000.00, and the assets do not exceed IDR 50,000,000, -. 
Table 2 The division of companies based on their asset sizes and turnovers

\begin{tabular}{lll}
\hline \multirow{2}{*}{$\begin{array}{c}\text { Size of } \\
\text { Enterprises }\end{array}$} & \multicolumn{2}{c}{ Criteria } \\
\cline { 2 - 3 } Micro & \multicolumn{1}{c}{ Asset } & \multicolumn{1}{c}{ Sales Revenue } \\
Small & $>$ IDR 50 million - IDR & $>$ IDR 300 million - \\
& 500 million & IDR 2.5 billion \\
Medium & $>$ IDR 500 million - IDR & $>$ IDR 2.5 billion - \\
& 10 billion & IDR 50 billion \\
Large & $>$ IDR 10 billion & $>$ IDR 50 billion
\end{tabular}

Source: Lembaga Pengembangan Perbankan Indonesia. 2015

In general, a characteristic of the businesses run by persons with disabilities is in the form of micro enterprises. There are many obstacles and challenges faced by entrepreneurs with disabilities, including:

1) Business sector often change, employers with disabilities often change the types of business they run. For example: a business run by Winarsih, who has spent so much time on sewing, at the same time trying to start another business i.e. food processing business. Persons with disabilities do not have a place for business and they usually rent a place, allowing them to move anytime.

2) Lack of financial management; not able to separate family finance from business finance. They usually spend business capital for household consumption, threatening business sustainability. Entrepreneurs with disabilities also have not done financial administration, even the simplest ones. Persons with disabilities on average have a low education and do not have access to vocational training, causing them to have insufficient skills.

3) PwDs on average also do not have an understanding of how to manage a business and do not have an adequate entrepreneurial spirit. They have a low understanding of how to operate a company, how to manage the marketing for products, how to manage human resources, and how to finance and use business funds. They even do not seem to have entrepreneurial spirit or resilience.

4) Persons with disabilities do not have access to banking. Due to mobility problems, they are reluctant to have bank accounts. This condition also makes it difficult for them to get access to loans to increase their capital. In general, entrepreneurs with disabilities do not have a business license or other legality requirements including tax identity.

\section{Barriers and Challenges in Each Micro-Based} Enterprise Sector Managed by Persons with Disabilities

The barriers and challenges faced by persons with disabilities can also be seen specifically in various business sectors run by disability-handling efforts. In a processing industry, when looking at the commodity aspect of the business which is run by persons with disabilities who still do not have experience in micro enterprises, the business has the following characteristics: The product quality is not standardized; there is no adequate technological access capability. In fact, they usually produce handmade products so that there is no standardized quality. The product design is also limited. These occur because they have limited knowledge and experience about products. They do not dare to try to create new designs. The product type is limited. Usually entrepreneurs with disabilities produce only a few products. Their production capability is still limited. If there is an order in large quantities, they face difficulty to fulfill the order. Even if they receive the order, the process will take a long time. To make situation worse, it is difficult for customers to make business relationships with entrepreneurs with disabilities because there are difficulties in product pricing as well as in determining the capacity of the products. Their raw materials are also less standardized because those materials are obtained from different sources. It will give impact on the quality of finished producs.

In agribusiness sector, the market is actually very wide open, especially regarding the fact that fishery product needs have not been met. However, it is difficult to meet such needs because generally the main problem is insufficient mastery of farming technology. There are not many agribusiness trainings available. A difficult problem to solve is related to overcoming the pest threat which hinders optimal production. There is also unbalanced pricing between a high cost of feed with the selling price of product, creating another challenge that is difficult to overcome. In fact, agribusiness in agriculture is a difficult field to undertake by persons with disabilities because it requires a strong physical condition.

Persons with disabilities are more often found to work in the general trading sector, i.e. groceries trade. However, since they face limited capital, their groceries store could only sell limited products, making it unattractive. Besides, the ability to purchase supplies at low prices is also a very important issue. On the other hand, transport business that is operated by entrepreneurs with disabilities is quite good. This business is in the form of motor taxi by using modified motorcycle. However, this business is not yet well managed and the number of vehicles is also still very limited. In terms of service businesses, the ones that PwDs mostly undertake are sewing and massage business. However, persons with disabilities are often not punctual, so the consumers have to wait for a long time for their clothes to finish, causing them to have a reduced trust from the community. Another service that many PwDs do is massage services for which the PwDs have no sufficient infrastructure and equipment, causing their massage business uninteresting. Some Disabled Persons Organizations make cooperation with hospitality industry in terms of providing massage service. 
D. Conduct reference studies to identify governmental programs in supporting self-employed persons with disabilities in the Province of Yogyakarta Special Region

When evaluating programs run by government related to their support for PwDs as set forth in LocalLocal Regulation No. 4 of 2012 on the Fulfillment of Rights to Employment especially in facilitating the expansion of employment opportunities through self-employment, there are some points to note as follows:

Every Disabled Employee has the right and opportunity to receive job training. Vocational training offered by the provincial government of Yogyakarta is done by the Integrated Rehabilitation Center for Persons with Disabilities (Balai Rehabilitasi Terpadu Penyandang Disabilitas/BRTPD) Yogyakarta. Meanwhile, at the regency level, this can be done through workshops owned by the work of social office or workplace training center owned by the labor service. Trainings can also be undertaken by the organizers of social rehabilitation.

The Integrated Rehabilitation Center for Persons with Disabilities Yogyakarta provides not only vocational trainings but also social rehabilitation and medical rehabilitation. Social rehabilitation includes physical, mental, social, spiritual, and psychological training, as well as speech therapy. Medical rehabilitation includes clinical services, physiotherapy, and hydrotheraphy. Skills training is intended to provide trainings in the form of massage, graphic design, computer, electronics, silver handicraft, leather craft, and sewing and embroidery. In addition to skill training, the Integrated Rehabilitation Center for Persons with Disabilities (BRTPD) Yogyakarta provides resocialization and social assistance programs. The center also provides further guidance in the form of guidance to improve the life of the community, business development, skill improvement, business improvement, and termination of relationships and service.In the meantime, the training undertaken at the district level is conducted in collaboration with local PwDs. The types of training provided are only the skills for handphone repair, caterers.

Local Government shall expand employment opportunities for Persons with Disabilities in the form of productive and sustainable self-employment. Training conducted at the district level is done in the short term and there is no guidance. Meanwhile, after the completion of trainings held by the government, there are no certificates that contain competence given. any organizations of Local Government which have duties and functions related to manpower are obliged to provide guidance to businesses managed by Persons with Disabilities. Training is emphasized more on providing skills training which is evident from the budget allocated for the empowerment of persons with disabilities, i.e. supporting self-employment and providing social assistance. The description of the allocation of local government budget, by taking a sample of the existing budget in the Local Government of Sleman is as follows:

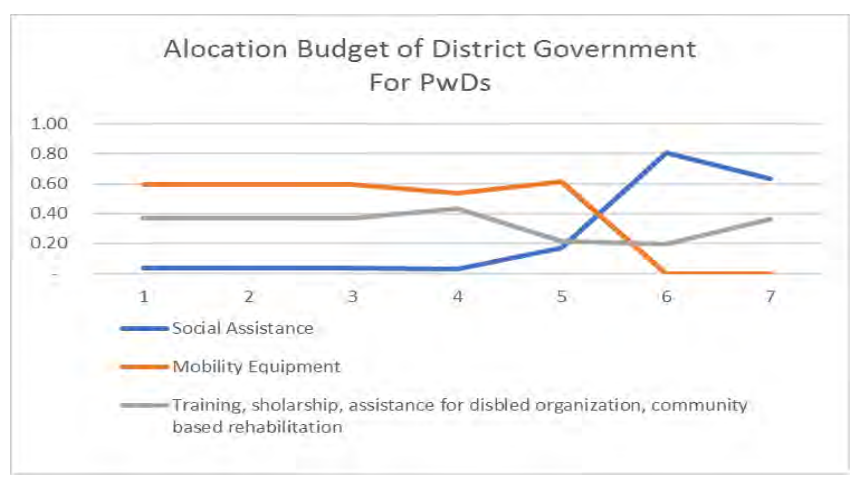

Figure 3. Budget Allocation of Sleman Regency Government for PwDs

Source: Local Planning and Development Agency (Bappeda) Sleman Regency

The budget for the empowerment of persons with disabilities has not been allocated separatedly because it is still integrated with the budget for scholarship, assistance for disabled organizations, and activities of community-based rehabilitation. The Local Government and Regency/Municipal Government do not seem to have made efforts to encourage and facilitate business actors to allocate some parts of their production or distribution processes to Persons with Disabilities. Private companies usually offer such thing directly to organizations of persons with disabilities, but due to lack of commitment, supervision and assistance from private companies, this activity does not work. In addition, Local Governments and District / Municipal Governments have not intensively facilitated Persons with Disabilities to obtain access to financial loans, either through banking or non-bank financial institutions, creating a challenge for entrepreneurs with disabilities in terms of capital.

\section{IV.CONCLUSIONS}

Based on the results of the data analysis, it can be concluded that:

A. Businesses run by persons with disabilities are still on the category of micro enterprises.

B. The types of businesses run by persons with disabiliteis are mostly in agriculture, animal husbandry and fishery sectors; processing industry; trade, transportation and services

C. There are weaknesses on business run by persons with disabilities such as the products offerred often change, the business place often moves, there is a lack of financial management where they cannot separate household finances from business finance. Besides, persons with disabilities on average have a low education. They generally have neither an understanding of how to manage a business neither adequate entrepreneurial spirit. 
Many persons with disabilities do not have access to banking. In general, businesses run by persons with disabilities do not have a business license.

D. The local government budgets for the empowerment of persons with disabilities in fulfilling the rights to employment through self-employment has not been allocated separatedly from other programs.

E. The issuance of Local Regulation No.4 of 2012 on the Protection and Fulfillment of the Rights of PwDs has not had a significant impact on the fulfillment of the rights of PwDs, including the right to employment, more specifically the right to self-employment.

F. The success of the empowerment programs for PwDs will be achieved if the obstacles and challenges faced by PwDs can be solved.

\section{ACKNOWLEDGMENT}

This research can be accomplished because of information provided by the local government, persons with disabilities, and disability organizations in the Yogyakarta province.

\section{REFERENCES}

[1] Irwanto., Eva Rahmi Kasim., Asmin Fransiska., Mimi Lusli., 2010., Siradj Okta Analisis Situasi Penyandang Disabilitas Di Indonesia: Sebuah Desk-Review. Pusat Kajian Disabilitas Fakultas Ilmu-Ilmu Sosial Dan Politik Universitas Indonesia Depok

[2] Republik Indonesia. 1997. Undang Undang 4/1997 tentang Penyandang Cacat. Lembaran Negara Republik Indonesia Tahun 1997 Nomor 9

[3] Republik Indonesia. 1974. Undang-Undang Nomor 6 Tahun 1974 Tentang Ketentuan-Ketentuan Pokok Kesejahteraan Sosial. Lembaran Negara Republik Indonesia Tahun 1974 Nomor 53.

[4] UN-ESCAP.,2003, Biwako Millennium Framework for Action Towards an Inclusive, Barrier-Free and Rights-Based Society for Persons with Disabilities in Asia and the Pacific. E/ESCAP/APDDP/4/Rev.1

[5] Saragih, Robinson W., 2013. Rencana Aksi Nasional Penyandang Cacat Indonesia. Tahun 2004- 2013. http://yanrehsosdki.blogspot.com/2013/03/rencana-aksi-nasionalpenyandang-cacat.html

[6] http://www.dinf.ne.jp/doc/english/twg/incheon strategy121123 e.h tml (download on January $15^{\text {th }} 2017$ ).

[7] Republik Indonesia. 2016. Undang-undang No 8 Tahun 2016 tentang Penyandang Disabilitras (Lembaran Negara Republik Indonesia Tahun 2016 Nomor 69).

[8] Republik Indonesia. 1974. Undang-Undang Nomor 6 Tahun 1974 Tentang Ketentuan-Ketentuan Pokok Kesejahteraan Sosial. Lembaran Negara Republik Indonesia Tahun 1974 Nomor 53.

[9] Republik Indonesia. 2016. Undang-undang No 8 Tahun 2016 tentang Penyandang Disabilitras (Lembaran Negara Republik Indonesia Tahun 2016 Nomor 69).

[10] Suryana., 2003., Kewirausahaan, Salemba empat, Jakarta.

[11] Benecdita Prihatin Dwi Riyanti., 2003.,Kewirausahaan dari sudut pandang kepribadian, Jakarta.

[12] Wiratmo., Masykur., 1996., Pengantar Kewiraswastaan, BPFE, Yogyakarta.

[13] Zimmerer, Thomas dan Scarborough, Norman (2004), Pengantar Kewirausahaan dan Manajemen Bisnis Kecil, Indeks, Jakarta

[14] United Nation-Department of Economic and Social Affairs Statistics., 2008. Division International Standard Industrial Classification of All Economic Activities. Series M No. 4/Rev.4. ISBN: 978-92-1-161518-0
[15] Winarto, Paulus., 2002., First Step To Be An Entrepreneur: berani Mengambil Risiko untuk Menjadi Kaya, PT Elex Media komputindo.

[16] Buhri Alma.,2009., Kewirausahaan, Alfabeta, Bandung.

[17] Mulyadi Nitisusastro.,2009.,Kewirausahaan dan Manajemen Usaha Kecil, Alfabeta, Bandung.

[18] Lembaga Pengembangan Perbankan Indonesia. 2015. Profil Bisnis Usaha Mikro, Kecil dan Menengah (UMKM), Jakarta. 